\title{
Review on Structures of Pesticide Targets
}

\author{
Xiangyang Li ${ }^{1}$, Xueqing Yang ${ }^{2}{ }^{D}$, Xiaodong Zheng ${ }^{3}$, Miao Bai ${ }^{4}$ and Deyu $\mathrm{Hu}^{1, *}$ \\ 1 State Key Laboratory Breeding Base of Green Pesticide and Agricultural Bioengineering, Key Laboratory of \\ Green Pesticide and Agricultural Bioengineering, Ministry of Education, Guizhou University, \\ Guiyang 550025, China; xyli1@gzu.edu.cn \\ 2 College of Plant Protection, Shenyang Agricultural University, Shenyang 110866, China; \\ sling233@hotmail.com \\ 3 College of Horticulture, Qingdao Agricultural University, Qingdao 266109, China; zheng.xiao.d@163.com \\ 4 College of Horticulture, Hunan Agricultural University, Changsha 410128, China; baimiao@hunau.edu.cn \\ * Correspondence: dyhu@gzu.edu.cn
}

Received: 28 August 2020; Accepted: 25 September 2020; Published: 28 September 2020

\begin{abstract}
Molecular targets play important roles in agrochemical discovery. Numerous pesticides target the key proteins in pathogens, insect, or plants. Investigating ligand-binding pockets and/or active sites in the proteins' structures is usually the first step in designing new green pesticides. Thus, molecular target structures are extremely important for the discovery and development of such pesticides. In this manuscript, we present a review of the molecular target structures, including those of antiviral, fungicidal, bactericidal, insecticidal, herbicidal, and plant growth-regulator targets, currently used in agrochemical research. The data will be helpful in pesticide design and the discovery of new green pesticides.
\end{abstract}

Keywords: molecular targets; structures; pesticides; agrochemicals; review

\section{Introduction}

The production of green pesticides is a very complex process, and there are many similarities among the design-synthesis-test-analysis cycles applied in agrochemical research. For example, a product cost of a commercial pesticide is approximately \$256 million, and it need screen more than 140,000 compounds and take more than 10 years. Thus, the discovery of a new commercial pesticide faces great challenges [1]. Recently, 862 pesticide types were reported globally. If these commercial pesticide types are classified according to the target of action, there are only 52, 26, and 20 kinds of targets for fungicides, insecticides, and herbicides, respectively [2]. In these targets, nucleic acids synthesis, cytoskeleton and motor protein, respiration, amino acids and protein synthesis, signal transduction, lipid synthesis or transport/membrane integrity or function, sterol biosynthesis, cell wall biosynthesis, melanin synthesis, host plant defense induction are the most used targets for studying the fungicides mechanisms of action [3]. Acetylcholinesterase, $\gamma$-aminobutyrie acid-gated chloride channel (GABACl), sodium channel, nicotinic acetylcholine receptor (nAChR), glutamate-gated chloride channel ( $\mathrm{GluCl})$, juvenile hormone, transient receptor potential vanilloid channel (TRPV), chitin synthase I, insect midgut membranes, mitochondrial ATP synthase, oxidative phosphorylation are the most used targets for studying the insecticides mechanisms of action [4]. Acetyl CoA carboxylase (ACC), acetolactate synthase/acetohydroxy acid synthase (AHAS), microtubule assembly, auxin, D1 serine 264/histidine 215, enolpyruvyl shikimate phosphate synthase, glutamine synthetase, phytoene desaturase, deoxy-D-xyulose phosphate synthase, protoporphyrinogen oxidase (PPO), very long-chain fatty acid synthesis, auxin transport, microtubule organization, hydroxyphenyl pyruvate dioxygenase (HPPD), cellulose synthesis, serine threonine protein phosphatase, solanesyl diphosphate synthase, homogentisate solanesyltransferase, lycopene cyclase 
are the most used targets for studying the herbicides mechanisms of action [5]. Many pesticides have been discovered that are based on the classical pesticide molecular targets (Table 1). This indicates that the potential new targets of pesticides are very limited, and most pesticides have been developed based on the classical pesticide molecular targets.

Table 1. Review of the mechanisms of commercial pesticides.

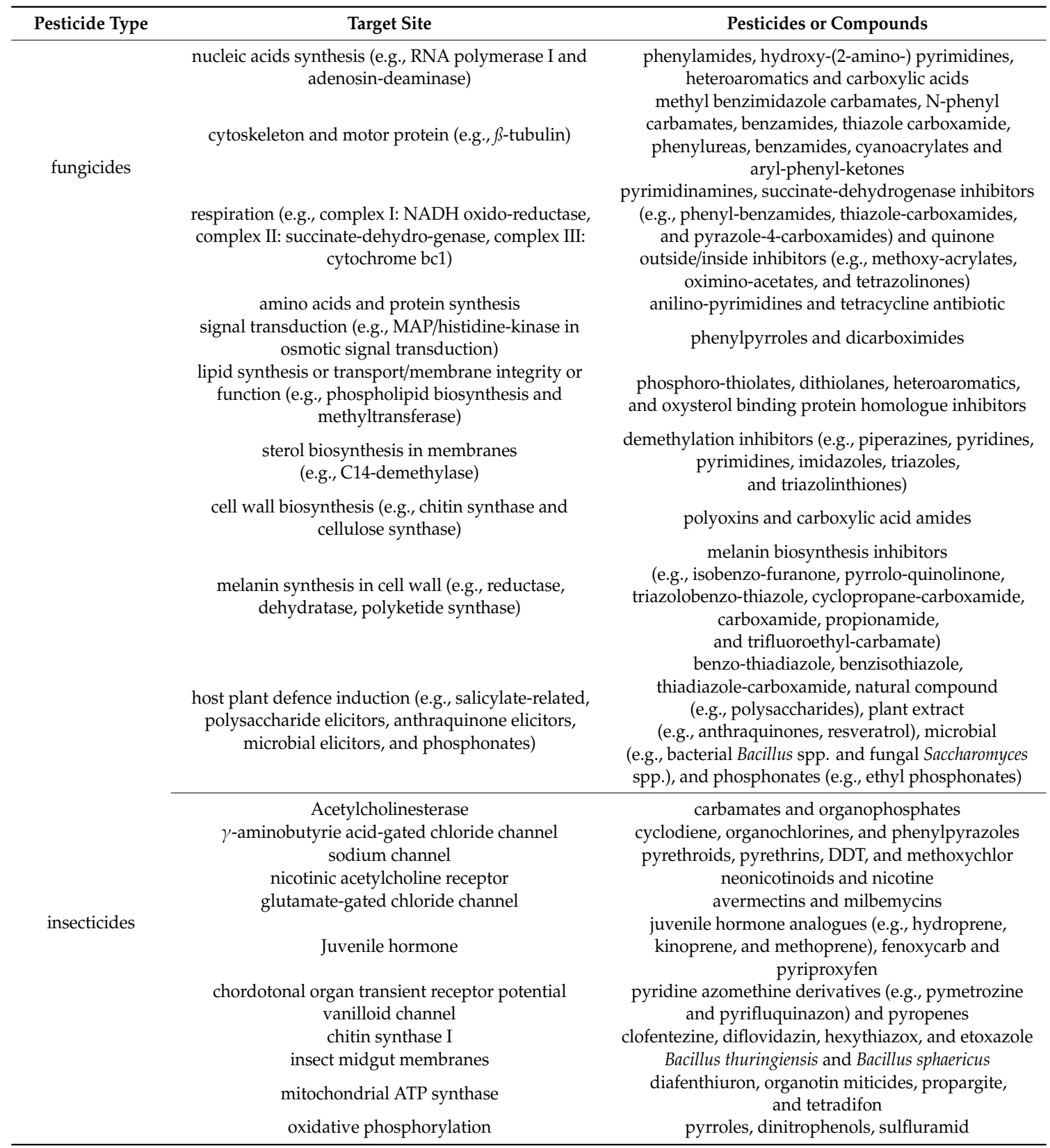


Table 1. Cont.

\begin{tabular}{|c|c|c|}
\hline Pesticide Type & Target Site & Pesticides or Compounds \\
\hline herbicides & $\begin{array}{c}\text { Acetyl CoA carboxylase } \\
\text { acetolactate synthase/acetohydroxy acid synthase } \\
\text { microtubule assembly } \\
\text { auxin } \\
\text { D1 serine 264/histidine } 215 \\
\text { enolpyruvyl shikimate phosphate synthase } \\
\text { glutamine synthetase } \\
\text { phytoene desaturase } \\
\text { deoxy-D-xyulose phosphate synthase } \\
\text { protoporphyrinogen oxidase } \\
\text { very long-chain fatty acid synthesis } \\
\text { auxin transport } \\
\text { microtubule organization } \\
\text { hydroxyphenyl pyruvate dioxygenase } \\
\text { cellulose synthesis } \\
\text { serine threonine protein phosphatase } \\
\text { solanesyl diphosphate synthase } \\
\text { homogentisate solanesyltransferase } \\
\text { lycopene cyclase }\end{array}$ & $\begin{array}{l}\text { Cyclohexanediones, and aryloxphenoxy-propionates } \\
\text { triazolopyrimidine, imidazolinone, sulfonylurea, } \\
\text { sulfonanilides, and pyrimidinylbenzoates } \\
\text { dinitroanilines, phosphoroamidates, and pyridines } \\
\text { phenoxy-carboxylates } \\
\text { triazines, ureas, triazinones, phenylcarbamates, and } \\
\text { amides } \\
\text { glyphosate } \\
\text { phosphinicacids } \\
\text { phenyl-ethers } \\
\text { isoxazolidinones } \\
\text { N-Phenyl-imides and diphenyl ethers } \\
\text { thiocarbamates, } \alpha \text {-chloroacetamides, benzofuranes, } \\
\text { and azolyl-carboxamides } \\
\text { aryl-carboxylates } \\
\text { carbamates } \\
\text { triketones and pyrazoles } \\
\text { alkylazines and nitriles } \\
\text { endothall } \\
\text { aclonifen } \\
\text { amitrole }\end{array}$ \\
\hline
\end{tabular}

Structural studies of molecular targets have paved a key pathway for understanding the pathogenic mechanism and for the discovery of new green pesticides. Driven by genomics, proteomics, bioinformatics technologies, and chemical biology, many structures of potential molecular targets have been identified owing to the emergence of highly active pesticides. Viral structural proteins, viral matrix protein, viral helicase, pyruvate kinase, dihydrolipoamide S-succinyltransferase (DLST), FabV, PYL family proteins (PYLs), coronatine insensitive 1 (COI1), gibberellin insensitive dwarf1 (GID1), hydrolase DWARF14 (D14), oxysterol-binding protein (OSBP), myosin I, and OfHex1 was applied to developing new green pesticide targets, while succinate dehydrogenase (SDH), tubulin, cytochrome bc1 complex, $14 \alpha$-demethylases (DM), nAChR, GluCl, GABACl, ryanodine receptor (RyR), TRPV, AHAS, PPO, HPPD, ACC, and dihydroxy-acid dehydratase (DHAD) are classical pesticide molecular targets (Figure 1). In this review, we summarize the antiviral, fungicide, bactericide, insecticide, herbicide, and plant growth regulator target structures involved in agrochemicals discovery.

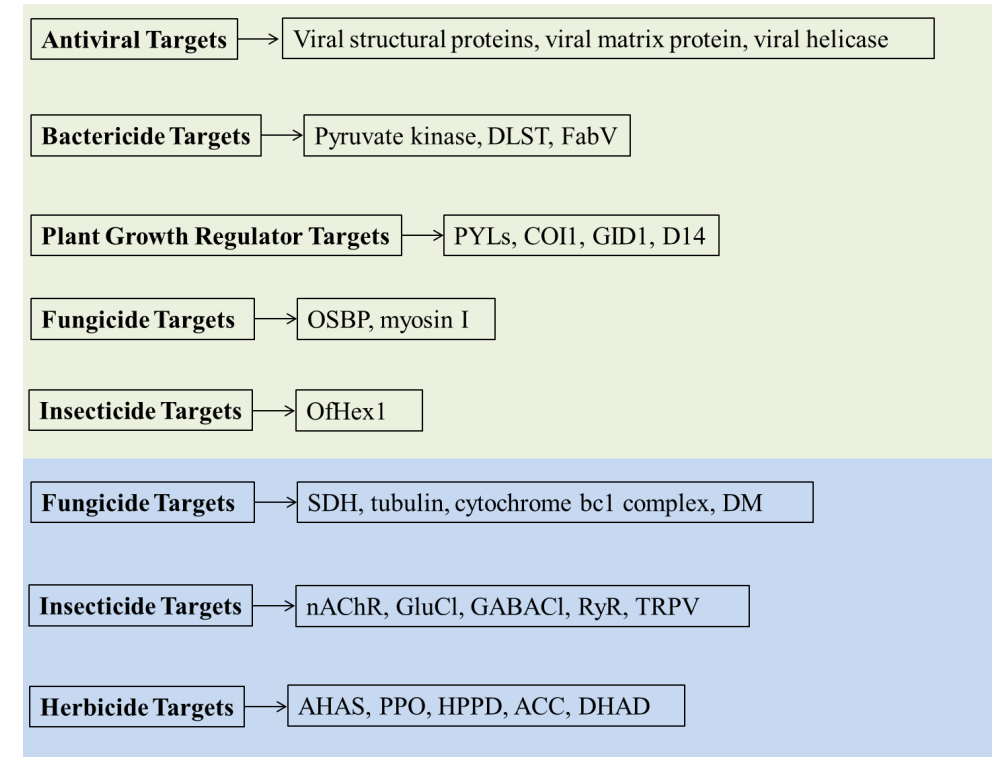

Figure 1. Reviewed the pesticide targets. The potential new molecular targets of pesticides are in light green area; the classical molecular targets of pesticides are in light blue area. 


\section{Pesticide Targets}

\subsection{Antiviral Targets}

Viral coat proteins $(\mathrm{CP})$, virus-like particles, viral helicases, viral matrix proteins, and capping enzymes have been used as targets to develop green anti-plant viral pesticides. The crystal structures of tobacco mosaic virus (TMV) CP [6], cucumber mosaic virus CP [7], potato virus $\mathrm{Y}$ virus-like particles [8], tomato mosaic virus helicase [9], rice black-streaked dwarf virus viral matrix protein P9-1 [10], southern rice black-streaked dwarf virus viral matrix protein P9-1 [11], and rice dwarf virus capping enzyme P5 (PDB ID: 5X6Y, unpublished) were solved using X-ray crystallography or cryo-electron microscopy. These structures are regarded as antiviral targets. Based on these structures, the mechanisms of some commercial antiviral agents were studied and revealed. Ningnanmycin breaks down the TMV disassembly by targeting CP $[12,13]$. Dufulin inhibits the replication of southern rice black-streaked dwarf virus by targeting viral matrix protein at a binding site located inside an internal pore that is stabilized by lateral hydrophobic interactions in the octameric structure $[14,15]$. An antiviral molecule targeting southern rice black-streaked dwarf virus P10 has been reported [16], and some commercial anti-TMV agents targeting TMV helicase protein have been screened $[17,18]$. It is noteworthy that ribavirin was screened using a viral helicase with a micro-molar affinity. Further analyses of the structural conformation showed that the target sites of ribavirin were in a shallow groove of the TMV helicase surrounded by D122, S139, D140, K143, and Y274 (indicated by the black arrows in Figure 2A,B [18]. The ribavirin-helicase structure provides a potent complex model for the antiviral discovery.

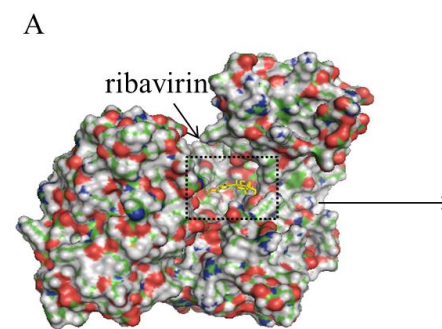

TMV helicase

$\mathrm{C}$

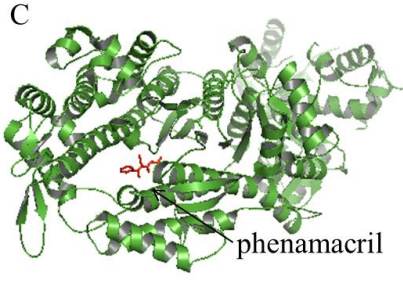

E

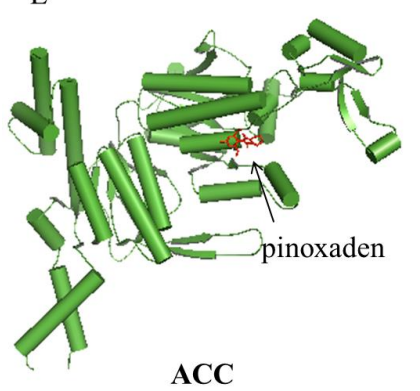

B

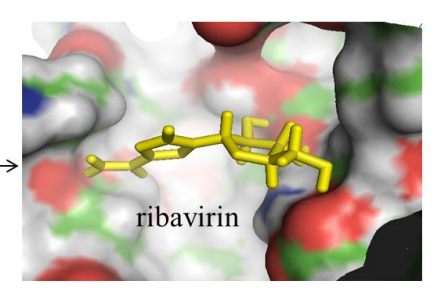

TMV helicase

D

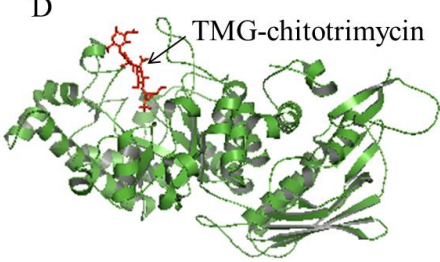

F

OfHex1

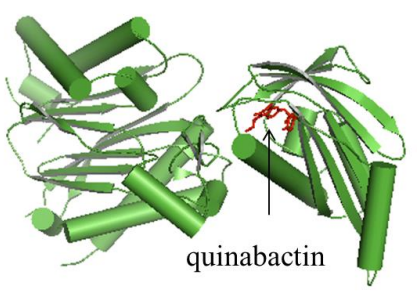

PYL2-HAB1

Figure 2. Review of the conformation of the complex structures in agrochemical research. (A) Ribavirin binding Tobacco mosaic virus (TMV) helicase, (B) Ribavirin in the TMV helicase pocket, (C) Phenamacril binding myosin I, (D) TMG-chitotrimycin binding Ofhex 1, (E) Pinoxaden bimding ACC, (F) PYL2-HAB1-quinabactin complex. 


\subsection{Fungicidal Targets}

Succinate dehydrogenase, tubulin, cytochrome bc1 complex, and $14 \alpha$-demethylases (DM) are classical and ideal targets for fungicide discovery. Among these, benzovindiflupyr is a successful succinate dehydrogenase (SDH) inhibitor, the mechanism of benzovindiflupyr is damaging the cell wall, membrane, and organelles, and further inhibits mycelial growth and conidial production of Bipolaris maydis [19], and the SDH and 3-nitropropionic acid complex structure were determined in Gallus gallus, which can form a covalent adduct of SDH with the side chain of $\operatorname{Arg}^{297}$ [20], Tubulin and boscalid complex structure was determined in G. gallus, while the tubulin and triazolopyrimidines-complex structure was confirmed in Bos taurus, which revealed that triazolopyrimidines are important for complex stability. The result indicated that triazolopyrimidines are microtubule stabilizers targeting the tubulin vinca site [21]. The structures of mitochondrial cytochrome bc1 in complex with famoxadone in B. Taurus [22], Rhodobacter sphaeroides [23], and G. gallus (PDB ID: 3L74, unpublished), were solved, which support an inhibitory mechanism of aromatic-aromatic interaction. The structures of cytochrome bc1 in complex with trifloxystrobin (PDB ID: 3L70, unpublished), azoxystrobin (PDB ID: 3L71, unpublished), triazolone (PDB ID: 3L73, unpublished), and fenamidone (PDB ID: 3L75, unpublished) in G. gallus were also solved. The structure of cytochrome bc1 complexed with azoxystrobin in R. sphaeroides was solved; the mechanism of azoxystrobin provides a gating mechanism for bifurcated catalyze electron transfer [24]. The discovery of new green fungicides was based on the structures of these mitochondrial cytochrome bc1 complexes $[25,26]$. The structures of DM complexed independently with S-tebuconazole, R-tebuconazole, S-desthio-prothioconazole, R-desthio-prothioconazole, fluquinconazole, prochloraz, and difenoconazole in Saccharomyces cerevisiae were solved, the complex structures reveal triazole-mediated coordination of all compounds and the specific orientation of compounds within the relatively hydrophobic binding site [27], and that of the complex of DM and posaconazole in Candida albicans was also confirmed, which provides a molecular mechanism for the potencies of drugs and the intrinsic resistance to fluconazole [28].

Recently, some new fungal targets, such as oxysterol-binding protein (OSBP) and myosin I, were identified. The OSBP-related ligand-binding domain at the $\mathrm{C}$ terminus is highly conserved with the specific substrate ergosterol in S. cerevisiae [29], with the specific substrate cholesterol in Kluyveromyces lactis [30], and with the specific substrate cholesterol in Homo sapiens [29,31]. A model of OSBP in Oomycetes was built on the basis of published homologous structures, which led to the synthesis and screening of new fungicidal compounds [32]. Myosin I is an important target in Fusarium graminearum [33], and the complex crystal structure of phenamacril-bound myosin I in F. graminearum was solved. It was discovered that phenamacril binds in the actin-binding cleft of a new allosteric pocket (Figure 2C) [34].

\subsection{Bactericidal Targets}

Compound YZK-C22 inhibits pyruvate kinase by reducing the expression of pyruvate kinase proteins in the metabolic process. Pyruvate kinase is a potential bactericidal target [35] and regarded as a novel target for the discovery of new fungicides [36]. Rice bacterial blight caused by Xanthomonas oryzae is the most serious bacterial disease of rice. The potential bactericidal target dihydrolipoamide S-succinyltransferase (DLST) was found using a sulfone compound, which used to confirm the involvement of DLST in the regulation of energy production [37]. The FabV of enoyl-ACP reductase is the key target enzyme in X. oryzae. The crystal structure of this protein was solved, and D111, Y236, and K245 were identified as key amino acid residues involved in the inhibition of the reductase activity [38]. This provided important information for the design and synthesis of anti-bacterial blight pesticides. 


\subsection{Insecticidal Targets}

At present, the truly commercial and valuable insecticides mainly target nicotinic acetylcholine receptor, glutamate-gated chloride channel, $\gamma$-aminobutyrate acid receptor, and ryanodine receptor (RyR) [39-43]. Breakthroughs have been made in the development of the insecticides benzamide and chlorantraniliprole, which target RyR, as well as cyclaniliprole. These were discovered based on the allosteric RyR structure [44].

Some new potent insecticide targets have been discovered. The crystal structure of the RyR's phosphorylation [45] and N-terminal [46] domains, as well as the SPRY2 domain from Plutella xylostella [47], were solved. These structures provide insights into the development of novel insecticides [48]. An insect transient receptor potential channel, transient receptor potential vanilloid, is a new and potent molecular target. Afidopyropen was discovered based on the structure of transient receptor potential vanilloid; the role of afidopyropen is a specific modulator of insect TRPV channels [49].

In addition, insect chitinases play crucial roles in chitinous tissues and other physiological processes, and thus are new and potent molecular targets. The crystal structure of insect beta-N-acetyl-D-hexosaminidase OfHex1 [50] and the co-crystal structures with its inhibitors, TMG-chitotriomycin (Figure 2D) [50], PUGNAc [51], and berberine [52], were successfully solved. OfHex1 is an enzyme that linked to an "open-close" mechanism at the entrance of the active site; the active pocket size of OfHex1 to TMG-chitotriomycin was $\operatorname{Trp}^{490}$, the active pocket size of OfHex1 to PUGNAc was Val ${ }^{327}$, and the active pocket size of OfHex1 to berberine was $\operatorname{Tr}{ }^{322}$, $\operatorname{Tr} \mathrm{p}^{483}$, Val ${ }^{484}$, which contributes to its inhibitory activity. These protein-ligand complexes formed a model for new green insecticide discovery $[53,54]$.

\subsection{Herbicidal Targets}

Acetohydroxyacid synthase (AHAS), protoporphyrinogen oxidase (PPO), and 4-hydroxyphenylpyruvate dioxygenase (HPPD) are widely recognized as the most important herbicidal targets.

For AHAS, the complex structure of its catalyzed subunit with monsulfuron-sulfuron from Arabidopsis thaliana was successfully solved, the mechanism of monsulfuron-sulfuron is break the cofactors thiamine diphosphate of AHAS [55], and AHAS was further selected as a potent target for herbicidal discovery [56].

The complex structure of PPO with acifluorfen $[57,58]$ was solved, which shows that the acifluorfen molecule binds to $\mathrm{Ile}^{176}$ by forming hydrophobic interactions, and the structural biology of PPO mutants and the mechanism of actions of herbicides based on PPO and its mutants were systematically studied as potent targets of novel herbicides [59-61].

In addition, the crystal structures of HPPDs from a variety of different species were systematically studied [62-64], and the structures in complex with NTBC [65] and a natural substrate were reported [66]. Thus, the binding mode of the substrate in the enzyme-catalyzed pocket of HPPD was revealed, which laid a solid foundation for an in-depth understanding of the mechanism of action of HPPD-inhibiting herbicides [67-70].

Some other herbicide targets were reported and utilized as potential molecular targets, such as acetyl CoA carboxylase (ACC) and dihydroxy-acid dehydratase (DHAD). ACC is regarded as a molecular target of phenylpyrazoline herbicide, and the mechanism of pinoxaden acts on ACC (Figure 2E) [71]. The full-length structure of DHAD was solved, and a natural product, aspterric acid, with herbicidal activity targeting the biosynthetic pathway of branched-chain amino acids DHAD was identified [72]. It provides a theoretical basis for designing novel herbicides with new mechanisms. 


\subsection{Plant Growth-Regulator Targets}

In the plant growth-regulator target field, the PYL family proteins (PYLs), the jasmonic acid receptor coronatine insensitive 1 (COI1), the gibberellin receptor gibberellin insensitive dwarf1 (GID1), and the strigolactone receptor hydrolase DWARF14 (D14) were new targets.

The PYLs are cellular abscisic acid (ABA) receptors. PYLs, through binding with ABA, undergo conformational changes that result in physical associations and the inhibition of the phosphatase activities of protein phosphatase 2C [73]. Interestingly, PYL2s are the most important molecular targets of plant growth regulators [74]. An X-ray structure of PYL2-quinabactin-HAB1 shows that quinabactin forms a hydrogen bond with the receptor or the protein phosphatase $2 \mathrm{C}$ "lock" hydrogen bond network (Figure 2F) [75]. It provides a theoretical basis for designing novel plant growth regulators.

COI1, GID1, and D14 are hormone receptors. A series of receptor structures have been solved. The structure of the complexes formed by COI1 with jasmonate zim domain [76], GID1 with gibberellin [77], D14 with strigolactone [78,79], and decreased apical dominance 2 (DAD2) bound to a quinazolinone derivative [80] were solved, and they could promote the discovery of new plant growth regulators.

\section{Discussion}

Target discovery and validation form one pathway to develop green pesticides. In this review, we summarized 64 potent crystal structures covered in 6 antiviral (Nos. 1-6), 23 fungicidal (Nos. 7-29), 2 bactericidal (Nos. 30 and 31), 7 insecticidal (Nos. 32-38), 14 herbicidal (Nos. 39-52), and 12 plant growth-regulator (Nos. 53-64) target-related agrochemical research studies in the PDB database (Table 2). Among them, 44 crystal structures are those of inhibitors or substrates (Figure 3), and these structural models provide the theoretical basis for discovering new green pesticides.

Table 2. Review of crystal targets with ligands in different species.

\begin{tabular}{|c|c|c|c|c|c|c|}
\hline No. & $\begin{array}{l}\text { Target } \\
\text { Protein }\end{array}$ & Species & Ligand & $\begin{array}{l}\text { Target } \\
\text { Type }\end{array}$ & $\begin{array}{l}\text { PDB } \\
\text { ID }\end{array}$ & Reference \\
\hline 1 & $\mathrm{CP}$ & Tobacco mosaic virus & no & \multirow{6}{*}{$\begin{array}{c}\text { antiviral } \\
\text { target }\end{array}$} & 4GQH & 6 \\
\hline 2 & P9-1 & $\begin{array}{c}\text { Southern rice black-streaked } \\
\text { dwarf virus }\end{array}$ & no & & $5 \mathrm{EFT}$ & unpublished \\
\hline 3 & P9-1 & Rice black-streaked dwarf virus & no & & 3VJJ & 10 \\
\hline 4 & Helicase & Tomato mosaic virus & no & & $3 \mathrm{VKW}$ & 9 \\
\hline 5 & VLP & Potato virus $Y$ & no & & $6 \mathrm{HXZ}$ & 8 \\
\hline 6 & P5 & Rice dwarf virus & S-adenosylmethionine & & $5 \times 6 Y$ & unpublished \\
\hline 7 & SDH & Gallus gallus & 3-nitropropionic acid & \multirow{13}{*}{$\begin{array}{c}\text { fungicide } \\
\text { target }\end{array}$} & 2FBW & 20 \\
\hline 8 & Tubulin & Bos Taurus & triazolopyrimidines & & $5 \mathrm{NJH}$ & 21 \\
\hline 9 & DM & Candida albicans & S-tebuconazole & & $5 \mathrm{EAB}$ & 27 \\
\hline 10 & DM & Candida albicans & R-tebuconazole & & $5 \mathrm{EAC}$ & 27 \\
\hline 11 & $\mathrm{DM}$ & Candida albicans & S-desthio-prothioconazole & & $5 \mathrm{EAD}$ & 27 \\
\hline 12 & $\mathrm{DM}$ & Candida albicans & R-desthio-prothioconazole & & $5 \mathrm{EAE}$ & 27 \\
\hline 13 & DM & Candida albicans & fluquinconazole & & $5 \mathrm{EAF}$ & 27 \\
\hline 14 & DM & Candida albicans & prochloraz & & $5 \mathrm{EAG}$ & 27 \\
\hline 15 & DM & Candida albicans & difenoconazole & & $5 \mathrm{EAH}$ & 27 \\
\hline 16 & $\mathrm{DM}$ & Candida albicans & posaconazole & & 5FSA & 28 \\
\hline 17 & DM & Candida albicans & posaconazole & & $5 \mathrm{TZ1}$ & 28 \\
\hline 18 & bc1 complex & Bos Taurus & famoxadone & & $1 \mathrm{LOL}$ & 22 \\
\hline 19 & bc1 complex & Rhodobacter sphaeroides & famoxadone & & $5 \mathrm{KKZ}$ & 23 \\
\hline
\end{tabular}


Table 2. Cont.

\begin{tabular}{|c|c|c|c|c|c|c|}
\hline No. & $\begin{array}{l}\text { Target } \\
\text { Protein }\end{array}$ & Species & Ligand & $\begin{array}{l}\text { Target } \\
\text { Type }\end{array}$ & $\begin{array}{l}\text { PDB } \\
\text { ID }\end{array}$ & Reference \\
\hline 20 & bc1 complex & Gallus gallus & trifloxystrobin & & 3L70 & unpublished \\
\hline 21 & bc1 complex & Gallus gallus & azoxystrobin & & 3L71 & unpublished \\
\hline 22 & bc1 complex & Gallus gallus & triazolone & & 3L73 & unpublished \\
\hline 23 & bc1 complex & Gallus gallus & famoxadone & & 3L74 & unpublished \\
\hline 24 & bc1 complex & Gallus gallus & fenamidone & & 3L75 & unpublished \\
\hline 25 & bc1 complex & Rhodobacter sphaeroides & azoxystrobin & & $6 \mathrm{NHH}$ & 24 \\
\hline 26 & Osh4 & Saccharomyces cerevisiae & ergosterol & & $1 \mathrm{ZHZ}$ & 29 \\
\hline 27 & Osh1 & Kluyveromyces lactis & Cholesterol & & $5 \mathrm{WVR}$ & 30 \\
\hline 28 & ORP1 & Homo sapiens & Cholesterol & & 5ZM5 & 29 \\
\hline 29 & Myosin I & Fusarium graminearum & Phenamacril & & 6UI4 & 34 \\
\hline 30 & $\begin{array}{l}\text { Pyruvate } \\
\text { kinase }\end{array}$ & Saccharomyces cerevisiae & no & bactericide & $1 \mathrm{~A} 3 \mathrm{~W}$ & 35 \\
\hline 31 & FabV & Xanthomonas oryzae & no & & 3S8M & 38 \\
\hline 32 & RyR PD & Plutella xylostella & no & & $6 \mathrm{~J} 6 \mathrm{O}$ & 45 \\
\hline 33 & RyR NTD & Plutella xylostella & no & & $5 Y 9 \mathrm{~V}$ & 46 \\
\hline 34 & RyR SPRY2 & diamondback moth & no & & $6 \mathrm{~J} 6 \mathrm{P}$ & 47 \\
\hline 35 & OfHex1 & Ostrinia furnacalis & no & $\begin{array}{c}\text { insecticide } \\
\text { target }\end{array}$ & 3NSM & 50 \\
\hline 36 & OfHex1 & Ostrinia furnacalis & TMG-chitotrimycin & & $3 \mathrm{NSN}$ & 50 \\
\hline 37 & OfHex1 & Ostrinia furnacalis & PUGNAc & & $3 \mathrm{OZP}$ & 51 \\
\hline 38 & OfHex1 & Ostrinia furnacalis & berberine & & $5 Y 0 V$ & 52 \\
\hline 39 & AHAS & Arabidopsis thaliana & monsulfuron-sulfuron & & 3EA4 & 55 \\
\hline 40 & $\mathrm{PPO}$ & Bacillus subtilis & acifluorfen & & 3I6D & 57 \\
\hline 41 & $\mathrm{PPO}$ & Homo sapiens & acifluorfen & & $3 \mathrm{NKS}$ & 58 \\
\hline 42 & HPPD & Arabidopsis thaliana & no & & 1SQD & 62 \\
\hline 43 & HPPD & Arabidopsis thaliana & no & & $1 \mathrm{TFZ}$ & 62 \\
\hline 44 & HPPD & Arabidopsis thaliana & no & & 1TG5 & 62 \\
\hline 45 & HPPD & Zea mays & no & herbicide & 1 SP8 & 63 \\
\hline 46 & HPPD & Homo sapiens & no & target & 3ISQ & unpublished \\
\hline 47 & HPPD & Rattus norvegicus & no & & 1SQI & 62 \\
\hline 48 & HPPD & Pseudomonas fluorescens & no & & $1 \mathrm{CJX}$ & 64 \\
\hline 49 & HPPD & Streptomyces avermitilis & NTBC & & $1 \mathrm{~T} 47$ & 65 \\
\hline 50 & HPPD & Arabidopsis thaliana & HPPA & & 5XGK & 66 \\
\hline 51 & DHAD & Arabidopsis thaliana & aspterric acid & & 5ZE4 & 72 \\
\hline 52 & ACC & Saccharomyces cerevisiae & pinoxaden & & 3PGQ & 71 \\
\hline 53 & PYL10-PP2C & Arabidopsis thaliana & $\mathrm{ABA}$ & & 3RT0 & 73 \\
\hline 54 & PYL10-PP2C & Arabidopsis thaliana & no & & 3RT2 & 73 \\
\hline 55 & PYL2-HAB1 & Arabidopsis thaliana & ABA & & $3 \mathrm{KDI}$ & 75 \\
\hline 56 & PYL2-HAB1 & Arabidopsis thaliana & quinabactin & & 4LA7 & 75 \\
\hline 57 & COI1-ASK1 & Arabidopsis thaliana & $\begin{array}{c}\text { incomplete JAZ1 } \\
\text { degron }\end{array}$ & plant growth & 3OGK & 76 \\
\hline 58 & COI1-ASK1 & Arabidopsis thaliana & $\begin{array}{l}\text { JA-isoleucine and the } \\
\text { JAZ1 degron }\end{array}$ & $\begin{array}{l}\text { regulator } \\
\text { target }\end{array}$ & 3OGL & 76 \\
\hline 59 & COI1-ASK1 & Arabidopsis thaliana & JAZ1 degron & & 3OGM & 76 \\
\hline 60 & GID1 & Oryza sativa Japonica Group & GA3 & & 3ED1 & 77 \\
\hline 61 & GID1 & Oryza sativa Japonica Group & GA4 & & 3EBL & 77 \\
\hline 62 & DAD2 & Petunia x hybrida & quinazolinedione & & $6 \mathrm{O} 5 \mathrm{~J}$ & 80 \\
\hline 63 & D14-D3-ASK1 & Arabidopsis thaliana & strigolactone & & $5 \mathrm{HZG}$ & 78 \\
\hline 64 & D3-ASK1 & Arabidopsis thaliana & no & & 5HYW & 78 \\
\hline
\end{tabular}




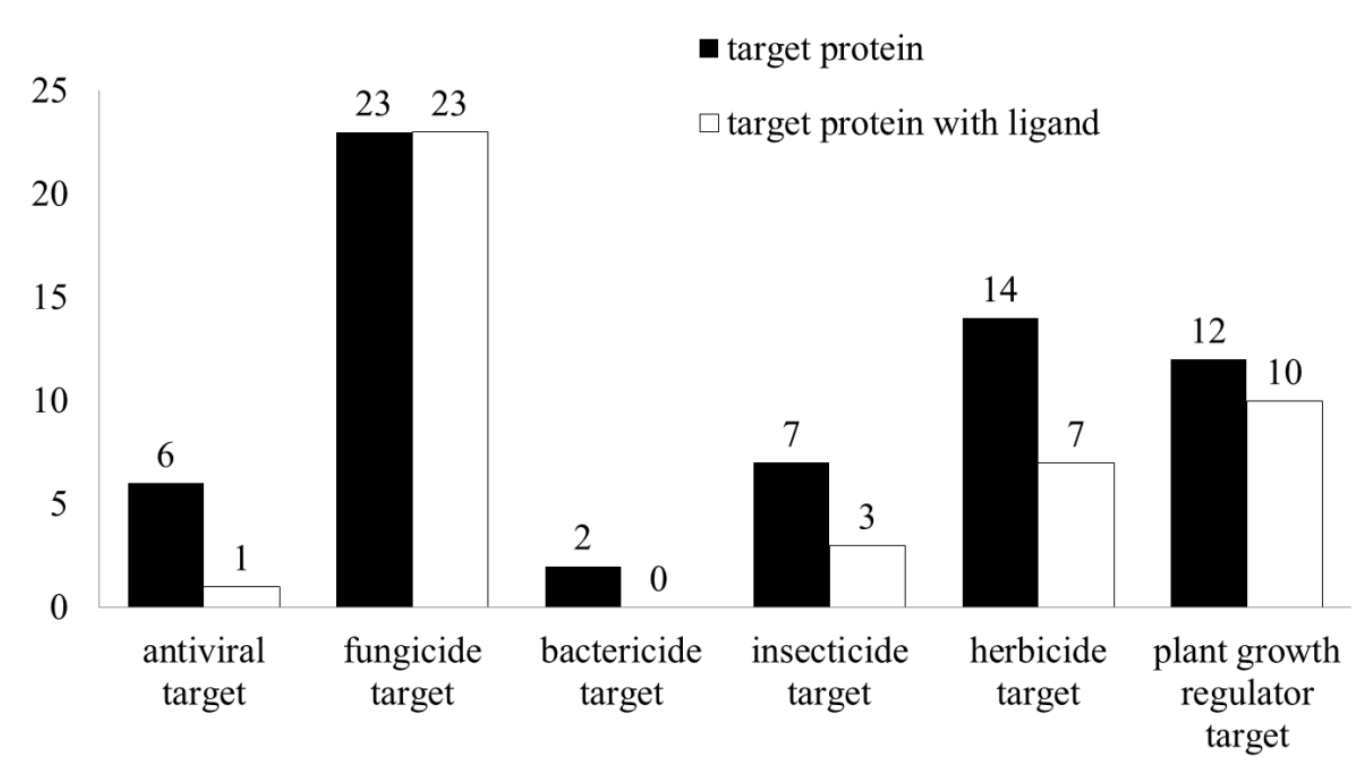

Figure 3. Summary of the number of protein structures in agrochemical research.

Among antiviral targets, $\mathrm{CP}$, helicase, matrix, and capping enzyme are the key targets, and the molecular mechanism is to inhibit the viral activity by direct breaking the $\mathrm{CP}$ assembly, and/or binding the target site. Among fungicidal and bactericidal targets, SDH, tubulin, cytochrome bc1 complex, DM, DLST, and FabV are the key targets, and the inhibitors play activities by damaging the cell wall, membrane, and organelles, and/or occupying binding site. Among insecticidal targets, nAChR, GluCl, GABACl, RyR, and TRPV are the key targets, and the mechanisms of insecticide usual modulate the conformation of targets to perform the insecticidal effect. Among herbicidal and plant growth-regulator targets, AHAS, PPO, HPPD, ACC, DHAD, PYLs, COI1, GID1, and D14 are the important targets, to study the regulation mechanism of ligand and protein receptors is an important way to discover new pesticides.

With the discovery and development of new green pesticides, many potential molecular targets have emerged. In particular, plant resistance protein, viral $\mathrm{CP}$, and viral minor $\mathrm{CP}$ have the most potential for antiviral discovery. For example, harpin binding protein- 1 is a potential target activated antiviral response in tobacco by antiviral agent dufulin [81], and tomato chlorosis virus (ToCV), CP play significant roles in sustaining the methyl cycle and S-adenosylmethionine-dependent methyltransferase activity and its minor $\mathrm{CP}$ play important roles in silencing suppression activity to counteract the RNA silencing-mediated defense response of the host $[82,83]$. Glucopyranoside derivatives, pyrimidine derivatives, $4(3 \mathrm{H})$-quinazolinone derivatives, and novel quinazolinone sulfide inhibitors targets ToCV coat protein with high anti-ToCV activity [84-87], and its minor coat protein is regarded as a novel target for the new green anti-ToCV inhibitors [88].

With deepening studies of functional genomics, proteomics, computer-aided design, and X-ray crystallography, many new potential molecular targets of pesticides have been identified and structurally characterized. In particular, in plant pathology, the structures of Phytophthora effectors PexRD54 and PexRD52, VR3a11 [89,90], and Avh240 [91] were solved, and the complex crystal structures of the Magnaporthe oryzae immune receptors RGA5A_S and RGA5A_S-AVR1-CO39 were solved [92,93], which aided in investigating the molecular mechanisms used by the rice disease-resistant protein RGA5 to recognize effectors. These structures provide a basis for studying the mutation-related mechanisms of effectors and provide important data for functional research and fungicide discovery. Interestingly, owing to the molecular dynamics, computational alanine scanning, and site-directed mutagenesis, residue Asn232 in the carboxylesterase gene of Cydia pomonella is considered a hot spot for binding with the organophosphate, acephate. Further functional analyses and mutation detection in field populations of C. pomonella indicated that the substitution N232A forms a new 
mutation associated with resistance to organophosphate insecticides in insects [94]. Thus, identifying and utilizing pesticide targets clarifies the molecular mechanisms and toxicity levels of agrochemical compounds at the molecular level. This finding provides important data that can be used to discover new green pesticides having low resistance. With the development of cryo-electron microscopy technology, many target proteins which were difficult to crystallize before can be obtained structures. With the further improvement of resolution, the structures based on cryo-electron microscopy have reached atomic resolution for the first time. This progress makes the interaction between pesticides and targets more accurate, and makes the structure-based drug design easier to realize. The recent interesting founding is the highest-resolution cryo-electron microscopy complex structure of RyR1 and the anthranilic diamide chlorantraniliprole. This complex structure reveals that chlorantraniliprole binds to a pocket on the cytoplasmic side in the voltage sensing domain, and it triggers channel opening and sustained releasing $\mathrm{Ca}^{2+}$, and promotes muscle paralysis and achieves insecticidal effect. More interesting, it found that chlorantraniliprole is selective to the diamondback moth over honeybee or mammalian RyRs [95]. These findings provide an important theoretical basis and a foundation for the development of new green pesticides aimed at overcoming resistance.

In the future, pesticide target structures will be at the frontier of agricultural scientific research. (1) Structural analysis is the basis of designing pesticides based on structure. With the progress of computing power and algorithm, under the condition of limited structure, the accuracy of homologous modeling and protein structure prediction is further improved, and the flux of virtual screening is also improved at the geometric level. The screening which was completed in the past few months can be completed in a few weeks or even days, and more and more effective potential pesticides can be obtained, which saves a lot of time and money compared with traditional screening methods. (2) Based on more and more resistant mutations being sequenced, more and more pesticide targets have been found in recent years, and the potential binding sites can be predicted. With the help of the new gene editing technology CRISPR-Cas-9, gene substitution and derivatization can be realized, and it is easier to determine pesticide targets. (3) Machine learning has played a great role in the field of medicine, although this technology is not widely used in the pesticide field. Halicin was developed based on AI, which opened a new door for humans to resist bacterial resistance [96]. We believe that in the near future, AI can also bring a new dawn for the structure-based drug design and development of pesticides.

Pesticide target will be the subject of new technology and innovations in modern agriculture. Target discovery has become the focus of technology and the source of innovation among global agrochemical giants. In 2015, the DuPont Company successfully developed the first fungicide, zorvec, which targets the OSBP and has an excellent control effect on crop diseases with low pesticide resistance. Industry analysts predict that the annual peak sales of zorvec will be $\$ 500$ million. In China, "Innovative research on new green pesticide and discovery of original target" has been chosen as one of the 60 major technical scientific and engineering problems. Thus, molecular targets will drive the emergence of a number of major new pesticide products, which are crucial for becoming the dominant power in the pesticide market in the future. Molecular target-oriented new green pesticide discovery and development are crucial for stimulating new green pesticide types that are highly efficient, produce low residue levels, and are environmentally safe.

\section{Conclusions}

Small molecule pesticides play specific therapeutic and preventive roles through target-binding to affect the functions of the entire cell or tissue. The safety and effectiveness of green pesticides depend on the functions and differentiation of targets. Our review summarized antiviral, fungicidal, bactericidal, insecticidal, herbicidal, and plant growth-regulator targets in agrochemical research, and pointed out the new potential pesticide targets, including antiviral, bactericidal, and plant growth-regulator targets. It shows that finding pesticide targets that are indispensable for life activities and differentiated among different species is a key scientific goal in the development of selective high-performance pesticides. 
Author Contributions: Original Draft Preparation, Writing, Review, and Art Work, X.L. and D.H.; Review, Editing, and Art Work, X.Y., X.Z., and M.B.; Conceptualization, X.L. and D.H.; Supervision, D.H. All authors have read and agreed to the published version of the manuscript.

Funding: This work is supported by National Key Research and Development Program of China (No.2017YFD0200503-3), and National Natural Science Foundation of China (No. 31960546), and Program of Introducing Talents of Discipline to Universities of China (111 Program, D20023).

Conflicts of Interest: The authors declare no conflict of interest.

\section{Abbreviations}

$\begin{array}{ll}\text { CP } & \text { Coat proteins } \\ \text { TMV } & \text { Tobacco mosaic virus } \\ \text { SDH } & \text { Succinate dehydrogenase } \\ \text { OSBP } & \text { Oxysterol-binding protein } \\ \text { DLST } & \text { Dihydrolipoamide S-succinyltransferase } \\ \text { DM } & 14 \alpha \text {-demethylases } \\ \text { GABACl } & \gamma \text {-aminobutyrie acid-gated chloride channel } \\ \text { nAChR } & \text { Nicotinic acetylcholine receptor } \\ \text { GluCl } & \text { Glutamate-gated chloride channel } \\ \text { TRPV } & \text { Transient receptor potential vanilloid channel } \\ \text { RyR } & \text { Ryanodine receptor } \\ \text { AHAS } & \text { Acetohydroxyacid synthase } \\ \text { PPO } & \text { Protoporphyrinogen oxidase } \\ \text { HPPD } & \text { 4-hydroxyphenylpyruvate dioxygenase } \\ \text { ACC } & \text { Acetyl CoA carboxylase } \\ \text { DHAD } & \text { Dihydroxy-acid dehydratase } \\ \text { PYLs } & \text { PYL family proteins } \\ \text { COI1 } & \text { Coronatine insensitive 1 } \\ \text { GID1 } & \text { Gibberellin receptor gibberellin insensitive dwarf1 } \\ \text { D14 } & \text { Strigolactone receptor hydrolase DWARF14 } \\ \text { DAD2 } & \text { Decreased apical dominance 2 } \\ \text { ABA } & \text { Abscisic acid } \\ \text { ToCV } & \text { Tomato chlorosis virus }\end{array}$

\section{References}

1. Clemens, L.; Stephane, J.; Torsten, L.; Andrew, P. Current challenges and trends in the discovery of agrochemicals. Science 2013, 341, 742-746.

2. Turner, J.A. The Pesticide Manual, 17th ed.; British Crop Protection Council: Hampshire, UK, 2015; pp. 1-1440.

3. Fungicide Resistance Action Committee. Fungal Control Agents Sorted by Cross Resistance Pattern and Mode of Action. 2020. Available online: https://www.frac.info/ (accessed on 16 August 2020).

4. IRAC International MoA Working Group. IRAC Mode of Action Classification Scheme. 2020. Available online: https://irac-online.org/modes-of-action/ (accessed on 16 August 2020).

5. The Global Herbicide Resistance Action Committee. HRAC Mode of Action Classification. 2020. Available online: https://www.hracglobal.com/herbicide-resistance (accessed on 16 August 2020).

6. Li, X.; Song, B.; Chen, X.; Wang, Z.; Zeng, M.; Yu, D.; Hu, D.; Chen, Z.; Jin, L.; Yang, S.; et al. Crystal structure of a four-layer aggregate of engineered TMV CP implies the importance of terminal residues for oligomer assembly. PLoS ONE 2013, 8, e77717. [CrossRef] [PubMed]

7. Smith, T.J.; Chase, E.; Schmidt, T.; Perry, K.L. The structure of cucumber mosaic virus and comparison to cowpea chlorotic mottle virus. J. Virol. 2000, 74, 7578-7586. [CrossRef] [PubMed]

8. Kežar, A.; Kavčič, L.; Polák, M.; Nováček, J.; Gutiérrez-Aguirre, I.; Žnidarič, M.T.; Coll, A.; Stare, K.; Gruden, K.; Ravnikar, M.; et al. Structural basis for the multitasking nature of the potato virus Y coat protein. Sci. Adv. 2019, 5, eaaw3808. [CrossRef] 
9. Nishikiori, M.; Sugiyama, S.; Xiang, H.; Niiyama, M.; Ishibashi, K.; Inoue, T.; Ishikawa, M.; Matsumura, H.; Katoh, E. Crystal structure of the superfamily 1 helicase from tomato mosaic virus. J. Virol. 2012, 86, 7565-7576. [CrossRef]

10. Akita, F.; Higashiura, A.; Shimizu, T.; Pu, Y.; Suzuki, M.; Uehara-Ichiki, T.; Sasaya, T.; Kanamaru, S.; Arisaka, F.; Tsukihara, T.; et al. Crystallographic analysis reveals octamerization of viroplasm matrix protein P9-1 of rice black streaked Dwarf virus. J. Virol. 2011, 86, 746-756. [CrossRef]

11. Li, X.; Zhang, W.; Ding, Y.; Wang, Z.; Wu, Z.; Yu, L.; Hu, D.; Li, P.; Song, B. Characterization of the importance of terminal residues for southern rice black-streaked dwarf virus P9-1 viroplasm formations. Protein Expr. Purif. 2015, 111, 98-104. [CrossRef]

12. Li, X.; Chen, Z.; Jin, L.; Hu, D.; Yang, S. New strategies and methods to study interactions between tobacco mosaic virus coat protein and its inhibitors. Int. J. Mol. Sci. 2016, 17, 252. [CrossRef]

13. Li, X.; Hao, G.; Wang, Q.; Chen, Z.; Ding, Y.; Yu, L.; Hu, D.; Song, B. Ningnanmycin inhibits tobacco mosaic virus virulence by binding directly to its coat protein discs. Oncotarget 2017, 8, 82446-82458. [CrossRef]

14. Li, X.; Liu, J.; Yang, X.; Ding, Y.; Wu, J.; Hu, D.; Song, B. Studies of binding interactions between Dufulin and southern rice black-streaked dwarf virus P9-1. Bioorganic Med. Chem. 2015, 23, 3629-3637. [CrossRef]

15. Wang, D.; Xie, X.; Gao, D.; Chen, K.; Chen, Z.; Jin, L.; Li, X.; Song, B. Dufulin intervenes the viroplasmic proteins as the mechanism of action against Southern rice black-streaked Dwarf virus. J. Agric. Food Chem. 2019, 67, 11380-11387. [CrossRef] [PubMed]

16. Ran, L.; Ding, Y.; Luo, L.; Gan, X.; Li, X.; Chen, Y.; Hu, D.; Song, B. Interaction research on an antiviral molecule that targets the coat protein of southern rice black-streaked dwarf virus. Int. J. Boil. Macromol. 2017, 103, 919-930. [CrossRef] [PubMed]

17. Li, X.-Y.; Chen, K.; Gao, D.; Wang, N.; Huang, M.; Zhu, H.; Kang, J. Binding studies between cytosinpeptidemycin and the superfamily 1 helicase protein of tobacco mosaic virus. RSC Adv. 2018, 8, 18952-18958. [CrossRef]

18. Wang, D.; Huang, M.; Gao, D.; Chen, K.; Xu, W.; Li, X.; Xu, X. Screening anti-TMV agents targeting tobacco mosaic virus helicase protein. Pestic. Biochem. Physiol. 2020, 166, 104449. [CrossRef]

19. Hou, Y.; Chen, Y.-L.; Wu, L.-Y.; Wang, J.-X.; Chen, C.; Zhou, M.-G. Baseline sensitivity of Bipolaris maydis to the novel succinate dehydrogenase inhibitor benzovindiflupyr and its efficacy. Pestic. Biochem. Physiol. 2018, 149, 81-88. [CrossRef]

20. Huang, L.-S.; Sun, G.; Cobessi, D.; Wang, A.C.; Shen, J.T.; Tung, E.Y.; Anderson, V.E.; Berry, E.A. 3-nitropropionic acid is a suicide inhibitor of mitochondrial respiration that, upon oxidation by complex II, forms a covalent adduct with a catalytic base arginine in the active site of the enzyme. J. Boil. Chem. 2005, 281, 5965-5972. [CrossRef]

21. Sáez-Calvo, G.; Sharma, A.; Balaguer, F.D.A.; Barasoain, I.; Rodríguez-Salarichs, J.; Olieric, N.; Muñoz-Hernández, H.; Berbís, M.Á.; Wendeborn, S.; Peñalva, M.A.; et al. Triazolopyrimidines are microtubule-stabilizing agents that bind the Vinca inhibitor site of tubulin. Cell Chem. Boil. 2017, 24, 737-750. [CrossRef]

22. Gao, X.; Wen, X.; Yu, C.; Esser, L.; Tsao, S.; Quinn, B.; Zhang, L.; Yu, L.; Xia, D. The crystal structure of mitochondrial cytochromebclin complex with famoxadone: The role of aromatic-aromatic interaction in inhibition. Biochemistry 2002, 41, 11692-11702. [CrossRef]

23. Esser, L.; Zhou, F.; Zhou, Y.; Xiao, Y.; Tang, W.-K.; Yu, C.-A.; Qin, Z.; Xia, D. Hydrogen bonding to the substrate is not required for Rieske iron-sulfur protein docking to the quinol oxidation site of complex III. J. Boil. Chem. 2016, 291, 25019-25031. [CrossRef]

24. Esser, L.; Zhou, F.; Yu, C.-A.; Xia, D. Crystal structure of bacterial cytochrome bc1 in complex with azoxystrobin reveals a conformational switch of the Rieske iron-sulfur protein subunit. J. Boil. Chem. 2019, 294, 12007-12019. [CrossRef]

25. Zhao, P.-L.; Wang, L.; Zhu, X.-L.; Huang, X.; Zhan, C.-G.; Wu, J.-W.; Yang, G.-F. Subnanomolar inhibitor of cytochromebc1complex designed by optimizing interaction with conformationally flexible residues. J. Am. Chem. Soc. 2010, 132, 185-194. [CrossRef] [PubMed]

26. Li, S.; Li, D.; Xiao, T.; Zhang, S.; Song, Z.; Ma, H. Design, synthesis, fungicidal activity, and unexpected docking model of the first chiral boscalid analogues containing oxazolines. J. Agric. Food Chem. 2016, 64, 8927-8934. [CrossRef] [PubMed] 
27. Tyndall, J.D.A.; Sabherwal, M.; Sagatova, A.A.; Keniya, M.V.; Negroni, J.; Wilson, R.K.; Woods, M.A.; Tietjen, K.; Monk, B.C. Structural and functional elucidation of yeast lanosterol $14 \alpha$-demethylase in complex with agrochemical antifungals. PLoS ONE 2016, 11, e0167485. [CrossRef]

28. Hargrove, T.Y.; Friggeri, L.; Wawrzak, Z.; Qi, A.; Hoekstra, W.J.; Schotzinger, R.J.; York, J.D.; Guengerich, F.P.; Lepesheva, G.I. Structural analyses of Candida albicanssterol $14 \alpha$-demethylase complexed with azole drugs address the molecular basis of azole-mediated inhibition of fungal sterol biosynthesis. J. Boil. Chem. 2017, 292, 6728-6743. [CrossRef] [PubMed]

29. Im, Y.J.; Raychaudhuri, S.; Prinz, W.A.; Hurley, J.H. Structural mechanism for sterol sensing and transport by OSBP-related proteins. Nature 2005, 437, 154-158. [CrossRef]

30. Manik, M.K.; Yang, H.; Tong, J.; Im, Y.J. Structure of yeast OSBP-related protein Osh1 reveals key determinants for lipid transport and protein targeting at the nucleus-vacuole junction. Structure 2017, 25, 617-629.e3. [CrossRef]

31. Dong, J.; Du, X.; Wang, H.; Wang, J.; Lu, C.; Chen, X.; Zhu, Z.; Luo, Z.; Yu, L.; Brown, A.J.; et al. Allosteric enhancement of ORP1-mediated cholesterol transport by PI(4,5)P2/PI(3,4)P2. Nat. Commun. 2019, 10, 829. [CrossRef]

32. Wu, Q.; Zhao, B.; Fan, Z.; Guo, X.; Yang, D.-Y.; Zhang, N.; Yu, B.; Zhou, S.; Zhao, J.; Chen, F. Discovery of novel piperidinylthiazole derivatives as broad-spectrum fungicidal candidates. J. Agric. Food Chem. 2019, 67, 1360-1370. [CrossRef]

33. Zheng, Z.; Hou, Y.; Cai, Y.; Zhang, Y.; Li, Y.; Zhou, M. Whole-genome sequencing reveals that mutations in myosin-5 confer resistance to the fungicide phenamacril in Fusarium graminearum. Sci. Rep. 2015, 5, 8248. [CrossRef]

34. Zhou, Y.; Zhou, X.E.; Gong, Y.; Zhu, Y.; Cao, X.; Brunzelle, J.S.; Xu, H.E.; Zhou, M.; Melcher, K.; Zhang, F. Structural basis of Fusarium myosin I inhibition by phenamacril. PLOS Pathog. 2020, 16, e1008323. [CrossRef]

35. Jurica, M.S.; Mesecar, A.D.; Heath, P.J.; Shi, W.; Nowak, T.; Stoddard, B.L. The allosteric regulation of pyruvate kinase by fructose-1,6-bisphosphate. Structure 1998, 6, 195-210. [CrossRef]

36. Zhao, B.; Fan, S.; Fan, Z.; Wang, H.; Zhang, N.; Guo, X.; Yang, D.; Wu, Q.; Yu, B.; Zhou, S. Discovery of pyruvate kinase as a novel target of new fungicide candidate 3-(4-Methyl-1,2,3-thiadiazolyl)-6-trichloromethyl-[1,2,4]-triazolo-[3,4-b][1,3,4]-thiadizole. J. Agric. Food Chem. 2018, 66, 12439-12452. [CrossRef] [PubMed]

37. Chen, B.; Long, Q.; Zhao, Y.-L.; Wu, Y.; Ge, S.; Wang, P.; Yang, C.-G.; Chi, Y.R.; Song, B.; Yang, S. Sulfone-based probes unraveled dihydrolipoamide S-Succinyltransferase as an unprecedented target in phytopathogens. J. Agric. Food Chem. 2019, 67, 6962-6969. [CrossRef]

38. Li, H.; Zhang, X.; Bi, L.; He, J.; Jiang, T. Determination of the crystal structure and active residues of FabV, the Enoyl-ACP reductase from xanthomonas oryzae. PLoS ONE 2011, 6, e26743. [CrossRef] [PubMed]

39. García-Reynaga, P.; Zhao, C.; Sarpong, R.; Casida, J.E. New GABA/glutamate receptor target for [3H] isoxazoline insecticide. Chem. Res. Toxicol. 2013, 26, 514-516. [CrossRef] [PubMed]

40. Onozaki, Y.; Horikoshi, R.; Ohno, I.; Kitsuda, S.; Durkin, K.A.; Suzuki, T.; Asahara, C.; Hiroki, N.; Komabashiri, R.; Shimizu, R.; et al. Flupyrimin: A novel insecticide acting at the nicotinic acetylcholine receptors. J. Agric. Food Chem. 2017, 65, 7865-7873. [CrossRef] [PubMed]

41. Casida, J.E. Radioligand recognition of insecticide targets. J. Agric. Food Chem. 2018, 66, 3277-3290. [CrossRef]

42. Liu1, G.; Wu, Y.; Gao, Y.; Ju, X.-L.; Ozoe, Y. Potential of competitive antagonists of insect ionotropic $\gamma$-aminobutyric acid receptors as insecticides. J. Agric. Food Chem. 2020, 68, 4760-4768. [CrossRef]

43. Casida, J.E. Golden age of RyR and GABA-R diamide and isoxazoline insecticides: Common genesis, serendipity, surprises, selectivity, and safety. Chem. Res. Toxicol. 2015, 28, 560-566. [CrossRef]

44. George, P.; Daniel, C.; James, D. New and selective ryanodine receptor activators for insect control. Bioorg. Med. Chem. 2009, 17, 4127-4133.

45. Xu, T.; Yuchi, Z. Crystal structure of diamondback moth ryanodine receptor Repeat34 domain reveals insect-specific phosphorylation sites. BMC Boil. 2019, 17, 77. [CrossRef] [PubMed]

46. Lin, L.; Liu, C.; Qin, J.; Wang, J.; Dong, S.; Chen, W.; He, W.-Y.; Gao, Q.; You, M.; Yuchi, Z. Crystal structure of ryanodine receptor $\mathrm{N}$-terminal domain from Plutella xylostella reveals two potential species-specific insecticide-targeting sites. Insect Biochem. Mol. Boil. 2018, 92, 73-83. [CrossRef] 
47. Zhou, Y.Y.; Ma, D.; Lin, L.; You, M.; Yuchi, Z.; You, S. Crystal structure of the ryanodine receptor SPRY2 domain from the diamondback moth provides insights into the development of novel insecticides. J. Agric. Food Chem. 2020, 68, 1731-1740. [CrossRef] [PubMed]

48. Samurkas, A.; Fan, X.; Ma, D.; Sundarraj, R.; Lin, L.; Yao, L.; Ma, R.; Jiang, H.; Cao, P.; Gao, Q.; et al. Discovery of potential species-specific green insecticides targeting the lepidopteran ryanodine receptor. J. Agric. Food Chem. 2020, 68, 4528-4537. [CrossRef] [PubMed]

49. Kandasamy, R.; London, D.; Stam, L.; Von Deyn, W.; Zhao, X.; Salgado, V.L.; Nesterov, A. Afidopyropen: New and potent modulator of insect transient receptor potential channels. Insect Biochem. Mol. Boil. 2017, 84, 32-39. [CrossRef]

50. Liu, T.; Zhang, H.; Liu, F.; Wu, Q.; Shen, X.; Yang, Q. Structural determinants of an insect beta-N-Acetyl-D-hexosaminidase specialized as a chitinolytic enzyme. J. Biol. Chem. 2011, 286, 4049-4058. [CrossRef]

51. Liu, T.; Zhang, H.; Liu, F.; Chen, L.; Shen, X.; Yang, Q. Active-pocket size differentiating insectile from bacterial chitinolytic $\beta-\mathrm{N}$-acetyl-D-hexosaminidases. Biochem. J. 2011, 438, 467-474. [CrossRef]

52. Duan, Y.; Liu, T.; Zhou, Y.; Dou, T.; Yang, Q. Glycoside hydrolase family 18 and 20 enzymes are novel targets of the traditional medicine berberine. J. Boil. Chem. 2018, 293, 15429-15438. [CrossRef]

53. Chen, W.; Zhou, Y.; Yang, Q. Structural dissection reveals a general mechanistic principle for group II chitinase (ChtII) inhibition. J. Boil. Chem. 2019, 294, 9358-9364. [CrossRef]

54. Chen, W.; Yang, Q. Development of novel pesticides targeting insect chitinases: A minireview and perspective. J. Agric. Food Chem. 2020, 68, 4559-4565. [CrossRef]

55. Wang, J.-G.; Lee, P.K.-M.; Dong, Y.; Pang, S.S.; Duggleby, R.G.; Li, Z.-M.; Guddat, L.W. Crystal structures of two novel sulfonylurea herbicides in complex with Arabidopsis thaliana acetohydroxyacid synthase. FEBS J. 2009, 276, 1282-1290. [CrossRef] [PubMed]

56. Liu, Y.-C.; Qu, R.-Y.; Chen, Q.; Yang, J.-F.; Cong-Wei, N.; Zhen, X.; Yang, G.-F. Triazolopyrimidines as a new herbicidal lead for combating weed resistance associated with acetohydroxyacid synthase mutation. J. Agric. Food Chem. 2016, 64, 4845-4857. [CrossRef] [PubMed]

57. Qin, X.; Sun, L.; Wen, X.; Yang, X.; Tan, Y.; Jin, H.; Cao, Q.; Zhou, W.; Xi, Z.; Shen, Y. Structural insight into unique properties of protoporphyrinogen oxidase from Bacillus subtilis. J. Struct. Boil. 2010, 170, 76-82. [CrossRef] [PubMed]

58. Qin, X.; Tan, Y.; Wang, L.; Wang, Z.; Wang, B.; Wen, X.; Yang, G.; Xi, Z.; Shen, Y. Structural insight into human variegate porphyria disease. FASEB J. 2010, 25, 653-664. [CrossRef] [PubMed]

59. Hao, G.-F.; Zuo, Y.; Yang, S.-G.; Chen, Q.; Zhang, Y.; Yin, C.-Y.; Niu, C.-W.; Xi, Z.; Yang, G.-F. Computational discovery of potent and bioselective protoporphyrinogen IX oxidase inhibitor via fragment deconstruction analysis. J. Agric. Food Chem. 2017, 65, 5581-5588. [CrossRef]

60. Hao, G.-F.; Tan, Y.; Yang, S.-G.; Wang, Z.-F.; Zhan, C.-G.; Xi, Z.; Yang, G.-F. Computational and experimental insights into the mechanism of substrate recognition and feedback inhibition of protoporphyrinogen oxidase. PLoS ONE 2013, 8, e69198. [CrossRef]

61. Hao, G.-F.; Zuo, Y.; Yang, S.-G.; Yang, G.-F. Protoporphyrinogen oxidase inhibitor: An ideal target for herbicide discovery. Chim. Int. J. Chem. 2011, 65, 961-969. [CrossRef]

62. Yang, C.; Pflugrath, J.W.; Camper, D.L.; Foster, M.L.; Pernich, D.J.; Walsh, T.A. Structural basis for herbicidal inhibitor selectivity revealed by comparison of crystal structures of plant and mammalian 4-hydroxyphenylpyruvate dioxygenases. Biochemistry 2004, 43, 10414-10423. [CrossRef]

63. Fritze, I.M.; Lindén, L.; Freigang, J.; Auerbach, G.; Huber, R.; Steinbacher, S. The crystal structures of zea mays and arabidopsis 4-hydroxyphenylpyruvate dioxygenase. Plant Physiol. 2004, 134, 1388-1400. [CrossRef]

64. Serre, L.; Sailland, A.; Sy, D.; Boudec, P.; Rolland, A.; Pebay-Peyroula, E.; Cohen-Addad, C. Crystal structure of Pseudomonas fluorescens 4-hydroxyphenylpyruvate dioxygenase: An enzyme involved in the tyrosine degradation pathway. Structure 1999, 7, 977-988. [CrossRef]

65. Brownlee, J.M.; Johnson-Winters, K.; Harrison, D.H.T.; Moran, G.R. Structure of the ferrous form of (4-Hydroxyphenyl) pyruvate Dioxygenase from Streptomyces avermitilisin complex with the therapeutic herbicide, NTBC. Biochemistry 2004, 43, 6370-6377. [CrossRef] [PubMed]

66. Lin, H.-Y.; Chen, X.; Chen, J.-N.; Wang, D.-W.; Wu, F.-X.; Lin, S.-Y.; Zhan, C.-G.; Wu, J.-W.; Yang, W.-C.; Yang, G.-F. Crystal structure of 4-hydroxyphenylpyruvate dioxygenase in complex with substrate reveals a new starting point for herbicide discovery. Research 2019, 2019, 2602414. [CrossRef] [PubMed] 
67. Wang, D.-W.; Lin, H.-Y.; Cao, R.-J.; Chen, T.; Wu, F.-X.; Hao, G.-F.; Chen, Q.; Yang, W.-C.; Yang, G.-F. Synthesis and herbicidal activity of triketone-quinoline hybrids as novel 4-hydroxyphenylpyruvate dioxygenase inhibitors. J. Agric. Food Chem. 2015, 63, 5587-5596. [CrossRef] [PubMed]

68. Wang, D.-W.; Lin, H.-Y.; Cao, R.-J.; Ming, Z.-Z.; Chen, T.; Hao, G.-F.; Yang, W.-C.; Yang, G.-F. Design, synthesis and herbicidal activity of novel quinazoline-2,4-diones as 4-hydroxyphenylpyruvate dioxygenase inhibitors. Pest Manag. Sci. 2014, 71, 1122-1132. [CrossRef] [PubMed]

69. Lin, H.; Yang, J.; Wang, D.; Hao, G.; Dong, J.; Wang, Y.; Yang, W.; Wu, J.; Zhan, C.; Yang, G. Molecular insights into the mechanism of 4-hydroxyphenylpyruvate dioxygenase inhibition: Enzyme kinetics, X-ray crystallography and computational simulations. FEBS J. 2019, 286, 975-990. [CrossRef]

70. Moosavi, B.; Yang, W.C.; Yang, G.F. 4-Hydroxyphenylpyruvate dioxygenase inhibitors: From chemical biology to agrochemicals ferdinand ndikuryayo. J. Agri. Food Chem. 2017, 65, 8523-8537.

71. Yu, L.P.C.; Kim, Y.S.; Tong, L. Mechanism for the inhibition of the carboxyltransferase domain of acetyl-coenzyme A carboxylase by pinoxaden. Proc. Natl. Acad. Sci. USA 2010, 107, 22072-22077. [CrossRef]

72. Yan, Y.; Liu, Q.; Zang, X.; Yuan, S.; Bat-Erdene, U.; Nguyen, C.; Gan, J.; Zhou, J.; Jacobsen, S.E.; Tang, Y. Resistance-gene-directed discovery of a natural-product herbicide with a new mode of action. Nature 2018, 559, 415-418. [CrossRef]

73. Hao, Q.; Yin, P.; Li, W.; Wang, L.; Yan, C.; Lin, Z.; Wu, J.Z.; Wang, J.; Yan, S.; Yan, N. The molecular basis of ABA-independent inhibition of PP2Cs by a subclass of PYL proteins. Mol. Cell 2011, 42, 662-672. [CrossRef]

74. Yin, P.; Fan, H.; Hao, Q.; Yuan, X.; Wu, D.; Pang, Y.; Yan, C.; Li, W.; Wang, J.; Yan, N. Structural insights into the mechanism of abscisic acid signaling by PYL proteins. Nat. Struct. Mol. Boil. 2009, 16, 1230-1236. [CrossRef]

75. Okamoto, M.; Peterson, F.C.; DeFries, A.; Park, S.-Y.; Endo, A.; Nambara, E.; Volkman, B.F.; Cutler, S.R. Activation of dimeric ABA receptors elicits guard cell closure, ABA-regulated gene expression, and drought tolerance. Proc. Natl. Acad. Sci. USA 2013, 110, 12132-12137. [CrossRef] [PubMed]

76. Sheard, L.B.; Tan, X.; Mao, H.; Withers, J.; Ben-Nissan, G.; Hinds, T.R.; Kobayashi, Y.; Hsu, F.-F.; Sharon, M.; Browse, J.; et al. Jasmonate perception by inositol-phosphate-potentiated COI1-JAZ co-receptor. Nature 2010, 468, 400-405. [CrossRef] [PubMed]

77. Shimada, A.; Ueguchi-Tanaka, M.; Nakatsu, T.; Nakajima, M.; Naoe, Y.; Ohmiya, H.; Kato, H.; Matsuoka, M. Structural basis for gibberellin recognition by its receptor GID1. Nature 2008, 456, 520-523. [CrossRef] [PubMed]

78. Yao, R.; Ming, Z.; Yan, L.; Li, S.; Wang, F.; Ma, S.; Yu, C.; Yang, M.; Chen, L.; Chen, L.; et al. DWARF14 is a non-canonical hormone receptor for strigolactone. Nature 2016, 536, 469-473. [CrossRef] [PubMed]

79. Seto, Y.; Yasui, R.; Kameoka, H.; Tamiru, M.; Cao, M.; Terauchi, R.; Sakurada, A.; Hirano, R.; Kisugi, T.; Hanada, A.; et al. Strigolactone perception and deactivation by a hydrolase receptor DWARF14. Nat. Commun. 2019, 10, 191. [CrossRef] [PubMed]

80. Hamiaux, C.; Larsen, L.; Lee, H.W.; Luo, Z.; Sharma, P.; Hawkins, B.C.; Perry, N.B.; Snowden, K.C. Chemical synthesis and characterization of a new quinazolinedione competitive antagonist for strigolactone receptors with an unexpected binding mode. Biochem. J. 2019, 476, 1843-1856. [CrossRef]

81. Chen, Z.; Zeng, M.; Song, B.; Hou, C.; Hu, D.; Li, X.; Wang, Z.; Fan, H.; Bi, L.; Liu, J.; et al. Dufulin activates HrBP1 to produce antiviral responses in tobacco. PLoS ONE 2012, 7, e37944. [CrossRef]

82. Cañizares, M.C.; Lozano-Durán, R.; Canto, T.; Bejarano, E.R.; Bisaro, D.M.; Navas-Castillo, J.; Moriones, E. Effects of the Crinivirus coat protein-interacting plant protein SAHH on post-transcriptional RNA silencing and its suppression. Mol. Plant-Microbe Interact. 2013, 26, 1004-1015. [CrossRef]

83. Cañizares, M.C.; Navas-Castillo, J.; Moriones, E. Multiple suppressors of RNA silencing encoded by both genomic RNAs of the crinivirus, Tomato chlorosis virus. Virology 2008, 379, 168-174. [CrossRef]

84. Xie, D.; Zhang, J.; Yang, H.; Liu, Y.; Hu, D.-Y.; Song, B. First anti-ToCV activity evaluation of glucopyranoside derivatives containing a dithioacetal moiety through a novel ToCVCP-oriented screening method. J. Agric. Food Chem. 2019, 67, 7243-7248. [CrossRef]

85. Zan, N.; Xie, D.; Li, M.; Jiang, D.; Song, B. Design, synthesis, and anti-ToCV activity of novel pyrimidine derivatives bearing a dithioacetal moiety that targets ToCV coat protein. J. Agric. Food Chem. 2020, 68, 6280-6285. [CrossRef] [PubMed] 
86. Zu, G.; Gan, X.; Xie, D.; Yang, H.; Zhang, A.; Li, S.; Hu, D.; Song, B. Design, synthesis, and anti-ToCV activity of novel 4(3H)-quinazolinone derivatives bearing dithioacetal moiety. J. Agric. Food Chem. 2020, 68, 5539-5544. [CrossRef] [PubMed]

87. Ran, L.; Yang, H.; Luo, L.; Huang, M.; Hu, D. Discovery of potent and novel quinazolinone sulfide inhibitors with Anti-ToCV activity. J. Agric. Food Chem. 2020, 68, 5302-5308. [CrossRef] [PubMed]

88. Yang, H.; Zu, G.; Liu, Y.; Xie, D.; Gan, X.; Song, B. Tomato chlorosis virus minor coat protein as a novel target to screen antiviral drugs. J. Agric. Food Chem. 2020, 68, 3425-3433. [CrossRef] [PubMed]

89. Boutemy, L.S.; King, S.R.F.; Win, J.; Hughes, R.K.; Clarke, T.A.; Blumenschein, T.M.A.; Kamoun, S.; Banfield, M.J. Structures of phytophthora RXLR effector proteins. J. Boil. Chem. 2011, 286, 35834-35842. [CrossRef]

90. Maqbool, A.; Hughes, R.K.; Dagdas, Y.; Tregidgo, N.; Zess, E.K.; Belhaj, K.; Round, A.; Bozkurt, T.O.; Kamoun, S.; Banfield, M. Structural basis of host autophagy-related Protein 8 (ATG8) binding by the Irish potato famine pathogen effector protein PexRD54. J. Boil. Chem. 2016, 291, 20270-20282. [CrossRef]

91. Guo, B.; Wang, H.; Yang, B.; Jiang, W.; Jing, M.; Li, H.; Xia, Y.; Xu, Y.; Hu, Q.; Wang, F.; et al. Phytophthora sojae effector PsAvh240 inhibits host aspartic protease secretion to promote infection. Mol. Plant 2019, 12, 552-564. [CrossRef]

92. Guo, L.; Cesari, S.; De Guillen, K.; Chalvon, V.; Mammri, L.; Ma, M.; Meusnier, I.; Bonnot, F.; Padilla, A.; Peng, Y.-L.; et al. Specific recognition of two MAX effectors by integrated HMA domains in plant immune receptors involves distinct binding surfaces. Proc. Natl. Acad. Sci. USA 2018, 115, 11637-11642. [CrossRef]

93. Guo, L.; Zhang, Y.; Ma, M.; Liu, Q.; Zhang, Y.; Peng, Y.; Liu, J. Crystallization of the rice immune receptor RGA5A_S with the rice blast fungus effector AVR1-CO39 prepared via mixture and tandem strategies. Acta Crystallogr. Sect. F. 2018, 74, 262-267. [CrossRef]

94. Yang, X.; Liu, J.Y.; Li, X.C.; Chen, M.H.; Zhang, Y.L. Key amino acid associated with acephate detoxification bycydia pomonellacarboxylesterase based on molecular dynamics with alanine scanning and site-directed mutagenesis. J. Chem. Inf. Model. 2014, 54, 1356-1370. [CrossRef]

95. Ma, R.; Haji-Ghassemi, O.; Ma, D.; Jiang, H.; Lin, L.; Yao, L.; Samurkas, A.; Li, Y.; Wang, Y.; Cao, P.; et al. Structural basis for diamide modulation of ryanodine receptor. Nat. Methods 2020, 10, 1-9. [CrossRef] [PubMed]

96. Stokes, J.M.; Yang, K.; Swanson, K.; Jin, W.; Cubillos-Ruiz, A.; Donghia, N.M.; MacNair, C.R.; French, S.; Carfrae, L.A.; Bloom-Ackermann, Z; et al. A deep learning approach to antibiotic discovery. Cell 2020, 180, 688-702. [CrossRef] [PubMed] 